\title{
Observations of equatorial ionization anomaly over Africa and Middle East during a year of deep minimum
}

\author{
Olawale Bolaji $^{1,2}$, Oluwafisayo Owolabi ${ }^{1}$, Elijah Falayi ${ }^{7}$, Emmanuel Jimoh $^{1}$, Afolabi Kotoye ${ }^{8}$, Olumide Odeyemi $^{1}$, \\ Babatunde Rabiu $^{3}$, Patricia Doherty ${ }^{4}$, Endawoke Yizengaw ${ }^{4}$, Yosuke Yamazaki ${ }^{5}$, Jacob Adeniyi ${ }^{6}$, Rafiat Kaka ${ }^{10}$, and \\ Kehinde Onanuga ${ }^{9}$
}

${ }^{1}$ Department of Physics, University of Lagos, Akoka - Yaba, Lagos, Nigeria

${ }^{2}$ Department of Physics, University of Tasmania, Hobart, Australia

${ }^{3}$ Center for Atmospheric Research (CAR), National Space Research and Development Agency (NASRDA), Kogi State University Campus, Anyigba, 270109, Nigeria

${ }^{4}$ Institute for Scientific Research, Boston College, Chestnut Hill, Massachusetts, USA

${ }^{5}$ Department of Physics, Lancaster University, Lancaster, UK

${ }^{6}$ Department of Physics, University of Ilorin, Kwara, Nigeria

${ }^{7}$ Department of Physics, Tai Solarin University of Education, Ijagun, Ijebu-Ode, Nigeria

${ }^{8}$ Abraham Adesanya Polytechnic, Ijebu-Igbo, Nigeria

${ }^{9}$ Department of Science Laboratory Technology, Lagos State Polytechnics, Lagos, Nigeria

${ }^{10}$ Department of Physics, Afe Babalola University, Ado-Ekiti, Nigeria

Correspondence to: Olawale Bolaji (oloriebimpjch2002@yahoo.co.uk)

Received: 13 July 2016 - Revised: 12 November 2016 - Accepted: 4 January 2017 - Published: 20 January 2017

\begin{abstract}
In this work, we investigated the veracity of an ion continuity equation in controlling equatorial ionization anomaly (EIA) morphology using total electron content (TEC) of 22 GPS receivers and three ground-based magnetometers (Magnetic Data Acquisition System, MAGDAS) over Africa and the Middle East (Africa-Middle East) during the quietest periods. Apart from further confirmation of the roles of equatorial electrojet (EEJ) and integrated equatorial electrojet (IEEJ) in determining hemispheric extent of EIA crest over higher latitudes, we found some additional roles played by thermospheric meridional neutral wind. Interestingly, the simultaneous observations of EIA crests in both hemispheres of Africa-Middle East showed different morphology compared to that reported over Asia. We also observed interesting latitudinal twin EIA crests domiciled at the low latitudes of the Northern Hemisphere. Our results further showed that weak EEJ strength associated with counter electrojet (CEJ) during sunrise hours could also trigger twin EIA crests over higher latitudes.
\end{abstract}

Keywords. Ionosphere (electric fields and currents)

\section{Introduction}

As one of the products of the ion continuity equation, the equatorial ionization anomaly (EIA) is a well-known phenomenon peculiar to the equatorial and low latitudes of the ionosphere. According to the ion continuity equation (Rishbeth, 1962), diffusion proceeds rapidly in the $\mathrm{F}$ region but more slowly in the lower ionosphere where collisions between charged and neutral particles dominate. This means that the lower ionosphere is characterized by the production and loss of ions without the transport process, while the $\mathrm{F}$ region and its top side are controlled by all parameters of the ion continuity equation. The $\mathrm{F}$ region ion density changes (Lei et al., 2008) are described by

$$
\frac{\partial N}{\partial t}=q-\beta N-\nabla(\boldsymbol{N} \boldsymbol{V})
$$

where $N$ is the ion concentration, $\beta$ is the loss coefficient, $q$ is the rate of production, $\nabla$ is the resulting rate of loss per unit volume and unit time, and $\boldsymbol{N} \boldsymbol{V}$ is the flux of electrons (or ions) due to transport. The last term in Eq. (1) represents transport effects due to electric fields, thermospheric meridional neutral winds, and ambipolar diffusion. This indicates 
that the last term of the ion continuity equation mostly represents the mechanisms responsible for hemispheric transportation of plasma that initiates EIA. It is worth noting that during the transportation of plasma over the $\mathrm{F}$ region, production and loss parameters are also active (Pedatella et al., 2014).

To mention a few, older experimental and simulation efforts of Appleton (1946), Bramley and Peart (1965), Moffet and Hanson (1965), Bramley and Young (1968) and Rush et al. (1969) described EIA as the redistribution of plasma across the hemispheres. This results in a peak (crest) in each hemisphere of the low latitudes and reduced plasma (trough) in each hemisphere slightly above the dip equator. In the Asian sector, Chen et al. (2008) reported that the changes in the horizontal magnetic field intensity (equatorial electrojet, EEJ), which are equivalent to eastward electric fields near the magnetic equator (Anderson et al., 2002) are very effective in regard to moving EIA crests to higher latitudes. Hence, the eastward electric field plays a vital role in electron density distribution over the equatorial and low latitudes of the ionosphere. Venkatesh et al. (2015) also investigated the role of EEJ in EIA using total electron content (TEC) data over the Indian and American sectors. They observed that the daily variations in EEJ strength significantly play a major role in the formation and development of EIA. One of the striking results from their works revealed that daily variability of EEJ strength associated with a slight depression near noon reproduced similar slight daytime depressions on EIA crests (twin peaks) over higher latitudes.

The literature above provides good knowledge of the EIA driven by the EEJ strength. The transportation of plasma to higher latitudes through the EIA phenomenon is wellknown to relate with eastward electric field/EEJ and thermospheric meridional neutral wind. Older experiments from GPS measurements that unveil thermospheric meridional neutral wind effect on plasma transportation in the $\mathrm{F}$ region (de Paula et al., 2015) are few compared with electric field/EEJ (Venkatesh et al., 2015; Chen et al., 2008). While the electric field/EEJ is transporting the plasma across higher latitudes within low latitudes, thermospheric meridional neutral wind is modulating the transporting plasma either poleward or equatorward. This work aims to increase the limited examples regarding thermospheric meridional neutral wind effect deduced from GPS TEC measurements and its role in transportation of plasma. This will improve our understanding of the competitive role played by thermospheric meridional neutral winds in relation to electric field/EEJ.

Chen et al. (2008) and Venkatesh et al. (2015) also investigated EIA morphology without considering selection of the quietest days for the estimates of solar quiet $\left(S_{\mathrm{q}}\right)$. Apart from the fact that the $S_{\mathrm{q}}$ current system is crucial to the estimates of EEJ strength (Rastogi and Klobuchar, 1990; Anderson et al., 2002; Bolaji et al., 2015), the response of EIA to EEJ strength during the quietest period has not been carried out over the African-Middle Eastern sector. One critical ques- tion that needs answered in order to improve our understanding of EEJ and IEEJ strength roles in the formation of fountain effect over Africa-Middle East is whether the responses of EIA to EEJ strength variability investigated in other regions be used as representations of African-Middle Eastern morphology. Similar questions that involved ionospheric irregularities and TEC from more than three stations simultaneously unveil different features in South America compared to Africa (de Abreu et al., 2014). This study is possible because the shortcoming due to paucity of ionospheric instrumentations in Africa-Middle East, which is an obstacle to carrying out EIA experiments, is gradually waning. More evidence of gradual growth in ionospheric instrumentations over Africa in recent times is an EIA study conducted by Joseph et al. (2015). However, their investigations are more focused on the characterization of EIA during a geomagnetic storm from 12 to 16 November 2012. Furthermore, one of the unique features associated Africa-Middle East that initiated this study is an opportunity to simultaneously investigate EIA in both the Northern and Southern hemispheres and compare our results with older works of Chen et al. (2008) in the Asian sector.

\section{Materials and methodology}

Figure 1 shows the map of Africa and the Middle East (Africa-Middle East) with location of stations used in this study. The green and red dots in Fig. 1 show GPS and Magnetic Data Acquisition System (MAGDAS) locations respectively. The choice of extending the GPS study into the Middle East from Africa in the Northern Hemisphere is to maintain the GPS locations between geographic longitudes 35 and $46^{\circ}$ E. Furthermore, in the Southern Hemisphere the GPS locations are between 20 and $35^{\circ} \mathrm{E}$. Table $1 \mathrm{a}$ and $\mathrm{b}$ show the list of station names, their codes, and geographic and geomagnetic coordinates. Records of 22 GPS receivers retrieved from African Geodetic Reference Frame (2015, http://www.afrefdata.org), International GNSS service (2016, http://www.igs.org), and three MAGDAS ground-based magnetometers available at http://magdas.serc.kyushu-u.ac.jp/ were used to investigate the EIA over Africa-Middle East. The year 2009, a year of geomagnetic deep minimum (Bolaji et al., 2015) in the last century (since 1901), characterized by 81 spotless days (http: //www.spaceweather.com/glossary/spotlessdays.htm) and an average annual sunspot number of 3.1, will be investigated.

Our choice of days and months selected from this year is based on simultaneous availability of data for both the TEC and the horizontal magnetic field (H-field) intensity observations. We found simultaneous records of TEC and H-field intensity over Africa-Middle East in January, February, March, and April 2009. For analysis of TEC and H-field intensity, the 5 quietest international days of the aforementioned months were obtained from the records of the Geosciences Australia 
Table 1. (a) Names and coordinates of the GPS stations under investigation. (b) Names and coordinates of MAGDAS stations used in this study.

\begin{tabular}{|c|c|c|c|c|c|c|}
\hline (a) & $\begin{array}{l}\text { Station name/ } \\
\text { country }\end{array}$ & $\begin{array}{l}\text { Station } \\
\text { codes }\end{array}$ & $\begin{array}{r}\text { Geographic } \\
\text { latitude }\end{array}$ & $\begin{array}{r}\text { Geomagnetic } \\
\text { longitude }\end{array}$ & $\begin{array}{r}\text { Geomagnetic } \\
\text { latitude }\end{array}$ & $\begin{array}{r}\text { Geomagnetic } \\
\text { longitude }\end{array}$ \\
\hline 1. & $\begin{array}{l}\text { Erdemli } \\
\text { (Turkey) }\end{array}$ & MERS & $36.81^{\circ} \mathrm{N}$ & $34.06^{\circ} \mathrm{E}$ & $30.71^{\circ} \mathrm{N}$ & $105.94^{\circ} \mathrm{E}$ \\
\hline 2. & $\begin{array}{l}\text { Mitzpe Ramon } \\
\text { (Israel) }\end{array}$ & RAMO & $30.61^{\circ} \mathrm{N}$ & $34.80^{\circ} \mathrm{E}$ & $23.38^{\circ} \mathrm{N}$ & $106.30^{\circ} \mathrm{E}$ \\
\hline 3. & $\begin{array}{l}\text { Halat Ammar } \\
\text { (Saudi Arabia) }\end{array}$ & HALY & $29.16^{\circ} \mathrm{N}$ & $36.07^{\circ} \mathrm{E}$ & $21.87^{\circ} \mathrm{N}$ & $107.53^{\circ} \mathrm{E}$ \\
\hline 4. & $\begin{array}{l}\text { Solar Village } \\
\text { (Saudi Arabia) }\end{array}$ & SOLA & $24.26^{\circ} \mathrm{N}$ & $46.51^{\circ} \mathrm{E}$ & $17.71^{\circ} \mathrm{N}$ & $118.16^{\circ} \mathrm{E}$ \\
\hline 5. & $\begin{array}{l}\text { Namas } \\
\text { (Saudi Arabia) }\end{array}$ & NAMA & $19.12^{\circ} \mathrm{N}$ & $42.48^{\circ} \mathrm{E}$ & $11.46^{\circ} \mathrm{N}$ & $114.05^{\circ} \mathrm{E}$ \\
\hline 6. & $\begin{array}{l}\text { Jizan } \\
\text { (Saudi Arabia) }\end{array}$ & JIZN & $16.88^{\circ} \mathrm{N}$ & $42.57^{\circ} \mathrm{E}$ & $9.02^{\circ} \mathrm{N}$ & $114.18^{\circ} \mathrm{E}$ \\
\hline 7. & $\begin{array}{l}\text { Sheba } \\
\text { (Eritrea) }\end{array}$ & SHEB & $15.85^{\circ} \mathrm{N}$ & $39.05^{\circ} \mathrm{E}$ & $7.56^{\circ} \mathrm{N}$ & $110.60^{\circ} \mathrm{E}$ \\
\hline 8. & $\begin{array}{l}\text { Asmara } \\
\text { (Eritrea) }\end{array}$ & ASMA & $15.34^{\circ} \mathrm{N}$ & $38.91^{\circ} \mathrm{E}$ & $6.79^{\circ} \mathrm{N}$ & $110.47^{\circ} \mathrm{E}$ \\
\hline 9. & $\begin{array}{l}\text { Mekele } \\
\text { (Ethiopia) }\end{array}$ & DAKE & $13.48^{\circ} \mathrm{N}$ & $39.48^{\circ} \mathrm{E}$ & $4.91^{\circ} \mathrm{N}$ & $111.09^{\circ} \mathrm{E}$ \\
\hline 10. & $\begin{array}{l}\text { Alem Maya } \\
\text { (Ethiopia) }\end{array}$ & DAMY & $9.36^{\circ} \mathrm{N}$ & $42.03^{\circ} \mathrm{E}$ & $0.90^{\circ} \mathrm{N}$ & $113.78^{\circ} \mathrm{E}$ \\
\hline 11. & $\begin{array}{l}\text { Nazret } \\
\text { (Ethiopia) }\end{array}$ & NAZR & $8.57^{\circ} \mathrm{N}$ & $39.29^{\circ} \mathrm{E}$ & $0.25^{\circ} \mathrm{S}$ & $111.01^{\circ} \mathrm{E}$ \\
\hline 12. & $\begin{array}{l}\text { Eldoret } \\
\text { (Kenya) }\end{array}$ & MOIU & $0.51^{\circ} \mathrm{N}$ & $35.36^{\circ} \mathrm{E}$ & $8.93^{\circ} \mathrm{S}$ & $107.08^{\circ} \mathrm{E}$ \\
\hline 13. & $\begin{array}{l}\text { Mount Baker } \\
\text { (Uganda) }\end{array}$ & BAKC & $0.36^{\circ} \mathrm{N}$ & $29.20^{\circ} \mathrm{E}$ & $9.24^{\circ} \mathrm{S}$ & $100.81^{\circ} \mathrm{E}$ \\
\hline 14. & $\begin{array}{l}\text { Entebbe } \\
\text { (Uganda) }\end{array}$ & EBBE & $0.05^{\circ} \mathrm{N}$ & $32.46^{\circ} \mathrm{E}$ & $9.52^{\circ} \mathrm{S}$ & $104.12^{\circ} \mathrm{E}$ \\
\hline 15. & $\begin{array}{l}\text { Dodoma } \\
\text { (Tanzania) }\end{array}$ & DODM & $6.16^{\circ} \mathrm{S}$ & $35.75^{\circ} \mathrm{E}$ & $16.56^{\circ} \mathrm{S}$ & $107.19^{\circ} \mathrm{E}$ \\
\hline 16. & $\begin{array}{l}\text { Tanzania } \\
\text { (Tanzania) }\end{array}$ & TANZ & $8.57^{\circ} \mathrm{S}$ & $39.29^{\circ} \mathrm{E}$ & $18.55^{\circ} \mathrm{S}$ & $110.57^{\circ} \mathrm{E}$ \\
\hline 17. & $\begin{array}{l}\text { Tukuyu } \\
\text { (Tanzania) }\end{array}$ & TUKC & $9.25^{\circ} \mathrm{S}$ & $33.65^{\circ} \mathrm{E}$ & $19.51^{\circ} \mathrm{S}$ & $104.82^{\circ} \mathrm{E}$ \\
\hline 18. & $\begin{array}{l}\text { Zambia } \\
\text { (Zambia) }\end{array}$ & ZAMB & $13.13^{\circ} \mathrm{S}$ & $27.85^{\circ} \mathrm{E}$ & $23.78^{\circ} \mathrm{S}$ & $98.34^{\circ} \mathrm{E}$ \\
\hline 19. & $\begin{array}{l}\text { Ngamiland } \\
\text { (Botswana) }\end{array}$ & MAUA & $19.19^{\circ} \mathrm{S}$ & $23.00^{\circ} \mathrm{E}$ & $30.11^{\circ} \mathrm{S}$ & $91.96^{\circ} \mathrm{E}$ \\
\hline 20. & $\begin{array}{l}\text { Hartebeesthoek } \\
\text { (South Africa) }\end{array}$ & HRAO & $25.89^{\circ} \mathrm{S}$ & $27.68^{\circ} \mathrm{E}$ & $36.32^{\circ} \mathrm{S}$ & $94.68^{\circ} \mathrm{E}$ \\
\hline 21. & $\begin{array}{l}\text { Richards Bay } \\
\text { (South Africa) }\end{array}$ & RBAY & $28.78^{\circ} \mathrm{S}$ & $32.03^{\circ} \mathrm{E}$ & $38.65^{\circ} \mathrm{S}$ & $97.89^{\circ} \mathrm{E}$ \\
\hline 22. & $\begin{array}{l}\text { Sutherland } \\
\text { (South Africa) }\end{array}$ & SUTH & $32.41^{\circ} \mathrm{S}$ & $20.67^{\circ} \mathrm{E}$ & $41.10^{\circ} \mathrm{S}$ & $84.60^{\circ} \mathrm{E}$ \\
\hline (b) & $\begin{array}{l}\text { Station name/ } \\
\text { country }\end{array}$ & $\begin{array}{l}\text { Station } \\
\text { codes }\end{array}$ & $\begin{array}{r}\text { Geographic } \\
\text { latitude }\end{array}$ & $\begin{array}{r}\text { Geographic } \\
\text { longitude }\end{array}$ & $\begin{array}{r}\text { Geomagnetic } \\
\text { latitude }\end{array}$ & $\begin{array}{r}\text { Geomagnetic } \\
\text { longitude }\end{array}$ \\
\hline 1. & $\begin{array}{l}\text { Addis Ababa } \\
\text { (Ethiopia) }\end{array}$ & $\mathrm{AAB}$ & $8.97^{\circ} \mathrm{N}$ & $38.75^{\circ} \mathrm{E}$ & $0.17^{\circ} \mathrm{N}$ & $110.48^{\circ} \mathrm{E}$ \\
\hline 2. & $\begin{array}{l}\text { Khartoum } \\
\text { (Sudan) }\end{array}$ & KRT & $15.63^{\circ} \mathrm{N}$ & $32.53^{\circ} \mathrm{E}$ & $6.03^{\circ} \mathrm{N}$ & $103.99^{\circ} \mathrm{E}$ \\
\hline 3. & $\begin{array}{l}\text { Nairobi } \\
\text { (Kenya) }\end{array}$ & NAB & $1.28^{\circ} \mathrm{S}$ & $36.81^{\circ} \mathrm{E}$ & $10.76^{\circ} \mathrm{S}$ & $108.51^{\circ} \mathrm{E}$ \\
\hline
\end{tabular}




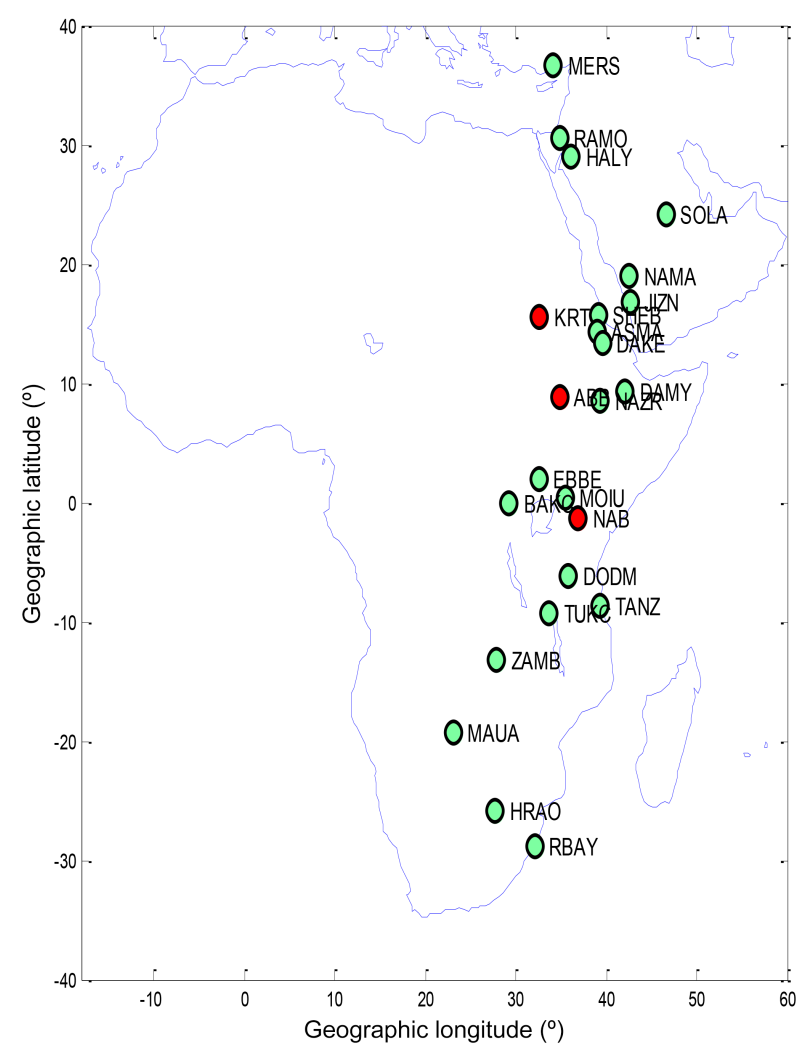

Figure 1. Map of Africa showing locations of study.

catalogue at http://www.ga.gov.au/oracle/geomag/iqd_form. jsp.

\subsection{Total electron content (TEC)}

Using differential delay technique on dual frequency measurements of GPS signal at $L_{1}(1575.42 \mathrm{MHz})$ and $L_{2}$ $(1227.60 \mathrm{MHz})$, the uncorrected slant total electron content (STEC) values were recorded at $1 \mathrm{~min}$ intervals and then corrected for satellite delays and biases (Bolaji et al., 2012). They were further converted into vertical total electron content, herein referred to as TEC.

\subsection{Equatorial electrojet (EEJ) and its integrated (IEEJ) strength}

The EEJ strength is evaluated by subtracting the $S_{\mathrm{q}}$ deduced from the H-field intensity (Bolaji et al., 2013) located outside the equatorial latitude at about \pm 5 to $\pm 10^{\circ}$ latitudes from the one located within the equatorial latitude of $\pm 3^{\circ}$ (Rastogi and Klobuchar, 1990; Anderson et al., 2002; Chen et al., 2008). In this work, our choice of station within the equatorial latitude is Addis Ababa (AAB), with geomagnetic coordinates $0.17^{\circ} \mathrm{N}, 110.48^{\circ} \mathrm{E}$. Outside the equatorial latitude in the Northern Hemisphere, we employed Khartoum (KRT), which is located at geomagnetic coordinates $6.03^{\circ} \mathrm{N}$, $103.99^{\circ}$ E. In the Southern Hemisphere, Nairobi (NAB) at geomagnetic coordinates $10.76^{\circ} \mathrm{S}, 108.51^{\circ} \mathrm{E}$ was employed.

The EEJ strength was estimated for both hemispheres, where the northern and southern EEJ strengths are represented with $E E J_{N}$ and $E E J_{S}$ respectively. In addition, the daytime integrated EEJ strength values for both the hemispheres were evaluated by integrating all the hourly EEJ strengths from 07:00 to 12:00 LT. This gives the daytime integrated equatorial electrojet (IEEJ) strength values for each day (Uemoto et al., 2010; Venkatesh et al., 2015).

\section{Results}

The contour plots of diurnal and latitudinal variations in TEC for 4 months (January, February, March, and April) in 2009 over the African-Middle Eastern sector are investigated. This is shown in the middle panel b (Figs. 2, 3, 4, and 5), with a colour bar beside each plot that shows the magnitudes of TEC in TEC units (TECUs). The left-handed side shows the geomagnetic latitudinal range of GPS stations and the righthanded side shows the GPS station codes investigated from the Northern to Southern hemispheres. The unfilled (white background) contours in the plots are due to data gaps. The top panel a (Figs. 2, 3, 4, and 5) and bottom panel c (Figs. 2, 3, 4, and 5) show the diurnal variations in the EEJ strength and the values of IEEJ strength in the Northern and Southern hemispheres respectively. The magnitudes of EEJ strength for the hemispheres are plotted on the left-handed side of the vertical axis against the local time (LT) on the horizontal axis.

In January (Fig. 2b), the northern EIA crests were moderately developed on all days. They are ranged between $\sim 23$ and $\sim 36$ TECU. On 17 January the minimum EIA crest was found at NAMA $\left(\sim 11^{\circ} \mathrm{N}\right.$, station abbreviations can be found in Table 1) and the maximum EIA crest was observed at ASMA $\left(\sim 7^{\circ} \mathrm{N}\right)$. The spread of TEC magnitudes in the range of $\sim 16-\sim 36$ TECU on all days in the Northern Hemisphere was between $\sim 5^{\circ} \mathrm{N}$ (DAKE) and $\sim 20^{\circ} \mathrm{N}$ (closer to HALY). Within this latitude $\left(\sim 5-\sim 20^{\circ} \mathrm{N}\right)$ along the EIA crest, two EIA crests were observed on all days associated with reduced TEC values straddling $\sim 8$ and $\sim 9^{\circ} \mathrm{N}$ (SHEB and JIZN). The two EIA crests associated with reduced TEC straddling, SHEB and JIZN, are higher at ASMA compared to NAMA on 3, 7, and 17 January, with exceptions on 11 and 12 January. On 3, 7, and 17 January, EIA crest magnitudes at ASMA were $\sim 33, \sim 33$, and $\sim 36$ TECU respectively. The corresponding lower EIA crest values at NAMA on these days were $\sim 27, \sim 24$, and $\sim 23$ TECU respectively. On 11 January, the EIA crest was $\sim 28$ TECU at NAMA and $\sim 27$ TECU at ASMA. The EIA crest on 12 January was $\sim 29$ and $\sim 25$ TECU at NAMA and ASMA respectively. In the Southern Hemisphere, the EIA crest magnitudes were between $\sim 19$ and $\sim 20$ TECU on all days investigated, with an exception on 3 January. The EIA crest was insignificant on 


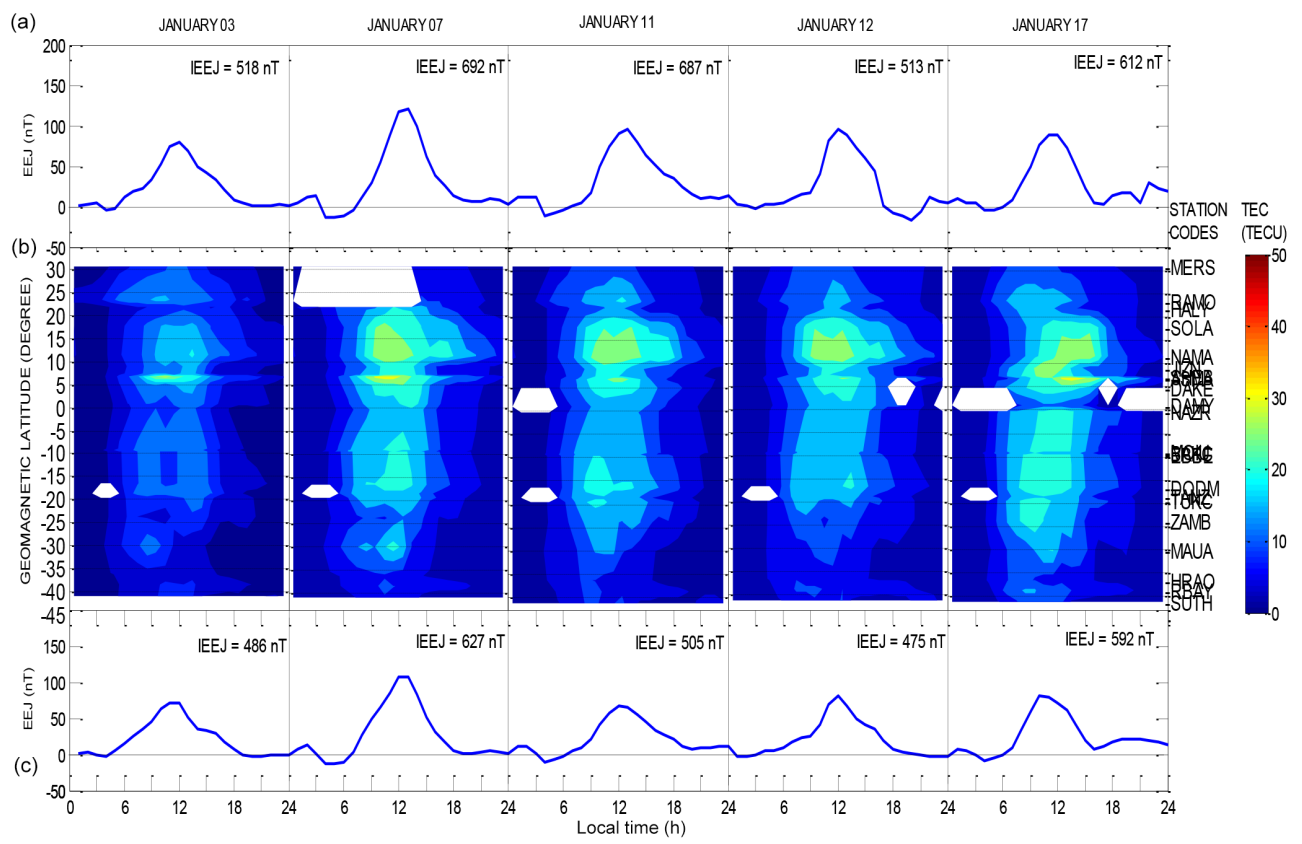

Figure 2. The TEC magnitudes of the quietest days, equatorial electrojet (EEJ) strength, and integrated EEJ strength in January.

3 January, straddled $\sim 9^{\circ} \mathrm{S}$ (MOIU) and $\sim 19^{\circ} \mathrm{S}$ (TANZ) on 7 January, was found between $\sim 9^{\circ} \mathrm{S}(\mathrm{BAKC})$ and $\sim 20^{\circ} \mathrm{S}$ (TUKC) on 11 January, observed at TANZ on 12 January, and straddled $\sim 0.3^{\circ} \mathrm{S}(\mathrm{NAZR})$ and $\sim 24^{\circ} \mathrm{S}(\mathrm{ZAMB})$ on 17 January.

In the corresponding plots (Fig. 2a and b), the highest EEJ strengths of $\sim 135$ and $\sim 117 \mathrm{nT}$ were observed in the Northern and Southern hemispheres respectively on 7 January. The highest IEEJ strengths of $\sim 692$ and $\sim 672 \mathrm{nT}$ were observed on 7 January in the Northern and Southern hemispheres respectively.

On all days investigated in February 2009 (Fig. 3b) in the Northern Hemisphere, two EIA crests associated with a reduced TEC magnitude at SHEB were obvious, with an exception on 2 February. The magnitude of a single EIA crest observed at ASMA on 2 February was $\sim 28$ TECU. A moderately developed EIA crest magnitude seen at ASMA on 8 and 10 February was $\sim 32$ TECU. The values of well-developed EIA crests at ASMA on 17 and 19 February were $\sim 50$ and $\sim 48$ TECU respectively. The magnitude of the second EIA crest found at JIZN on 8, 10, and 19 February were $\sim 20$, $\sim 21$, and $\sim 18$ TECU respectively. On 17 February the second EIA crest value observed at NAMA was $\sim 18$ TECU. In the Southern Hemisphere, no visible EIA crest was observed on 2 February. A less-developed EIA crest in the range of $\sim 18-\sim 20$ TECU straddled NAZR and TUKC, TANZ and TUKC, and BAKC and TUKC on 8,10 , and 19 February respectively. On 17 February a moderately developed EIA crest ( 26 TECU) was observed at TUKC.

Maximum EEJ strengths of $\sim 162 \mathrm{nT}$ (Northern Hemisphere) and $\sim 186 \mathrm{nT}$ (Southern Hemisphere) were observed on 10 February (Fig. 3a and c). On the same 10 February afternoon, a counter electrojet (CEJ) maximum value of $\sim-25 \mathrm{nT}$ was observed around 16:00 LT in the Southern Hemisphere. In the Northern Hemisphere, a minimum CEJ value of $\sim-10 \mathrm{nT}$ in the afternoon was seen around 16:00 LT on the same day. On 10 February, the highest IEEJ strength of 887 and $882 \mathrm{nT}$ was observed in the Southern and Northern hemispheres respectively.

In March (Fig. 4b), the EIA crests were well-formed, both in the Northern and Southern hemispheres on 2 March ( $\sim 36$ TECU in the north, $\sim 26$ TECU in the south), 6 March ( $\sim 48$ TECU in the north, $\sim 29$ TECU in the south), 9 March ( $\sim 49$ TECU in the north, $\sim 25$ TECU in the south), and 18 March $(\sim 37$ TECU in the north, $\sim 29$ TECU in the south). An exception was found on 7 March with a lessdeveloped EIA crest in the range of $\sim 18-\sim 20$ TECU straddling MOIU and TUKC. This signifies that the EIA crests were well-developed in the Northern Hemisphere compared to the Southern Hemisphere on all of the days investigated. In addition, there were two EIA crests in the Northern Hemisphere at different latitudes similar to our observations in January and February, with an exception on 2 March. The first well-developed EIA crest in the Northern Hemisphere was seen at ASMA on all of the days, and the second less-developed EIA crest was found at SOLA on 6 March. On 9 March, the moderately developed EIA crest was observed at NAMA and straddled NAMA and SOLA on 7 and 18 March.

In Fig. 4a and c, maximum EEJ strength values of $\sim 120$ and $\sim 122 \mathrm{nT}$ were found on 18 and 7 March in the Northern and Southern hemispheres respectively. On 7 March, the 


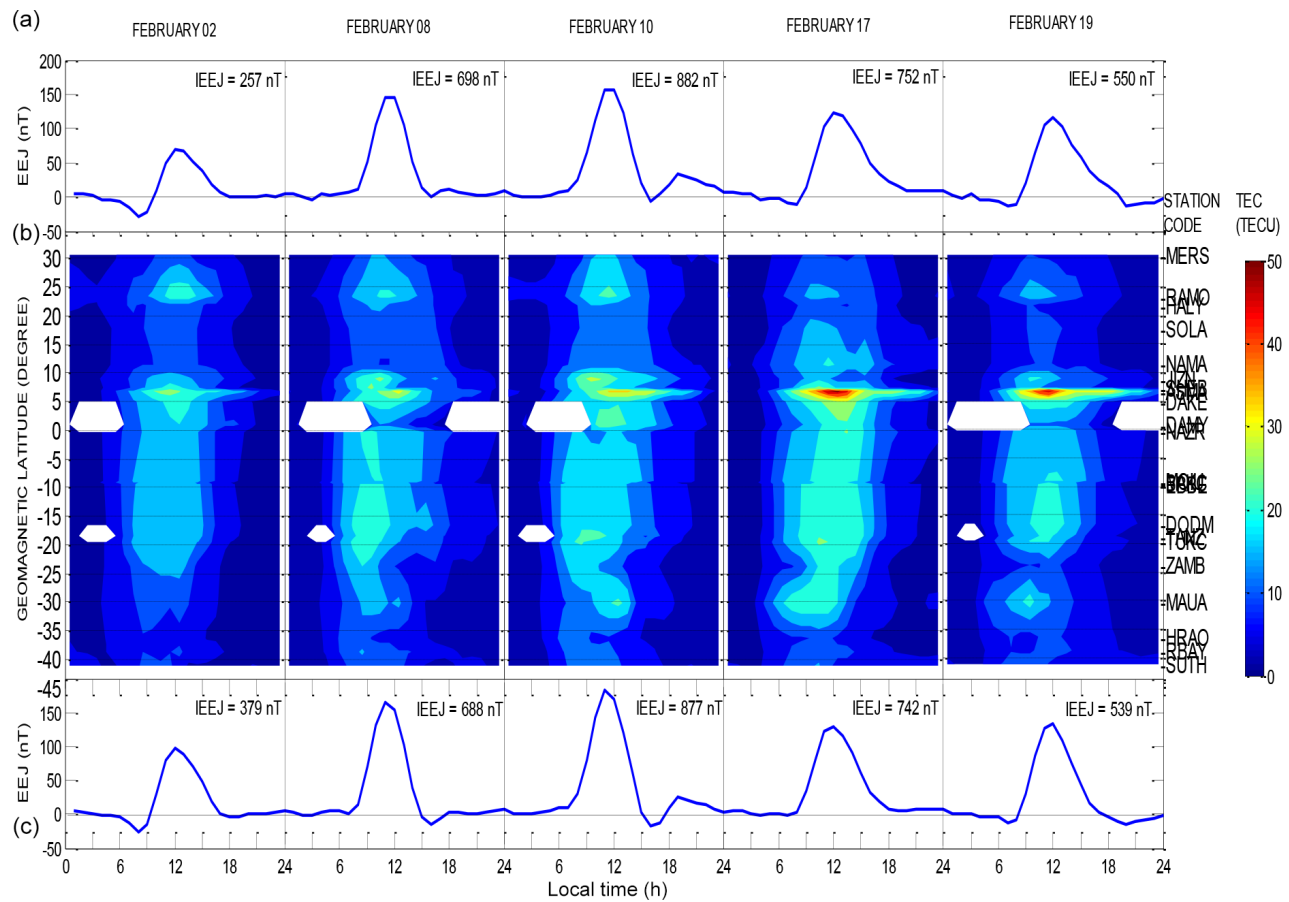

Figure 3. The TEC magnitudes of the quietest days, equatorial electrojet (EEJ) strength, and integrated EEJ strength in February.

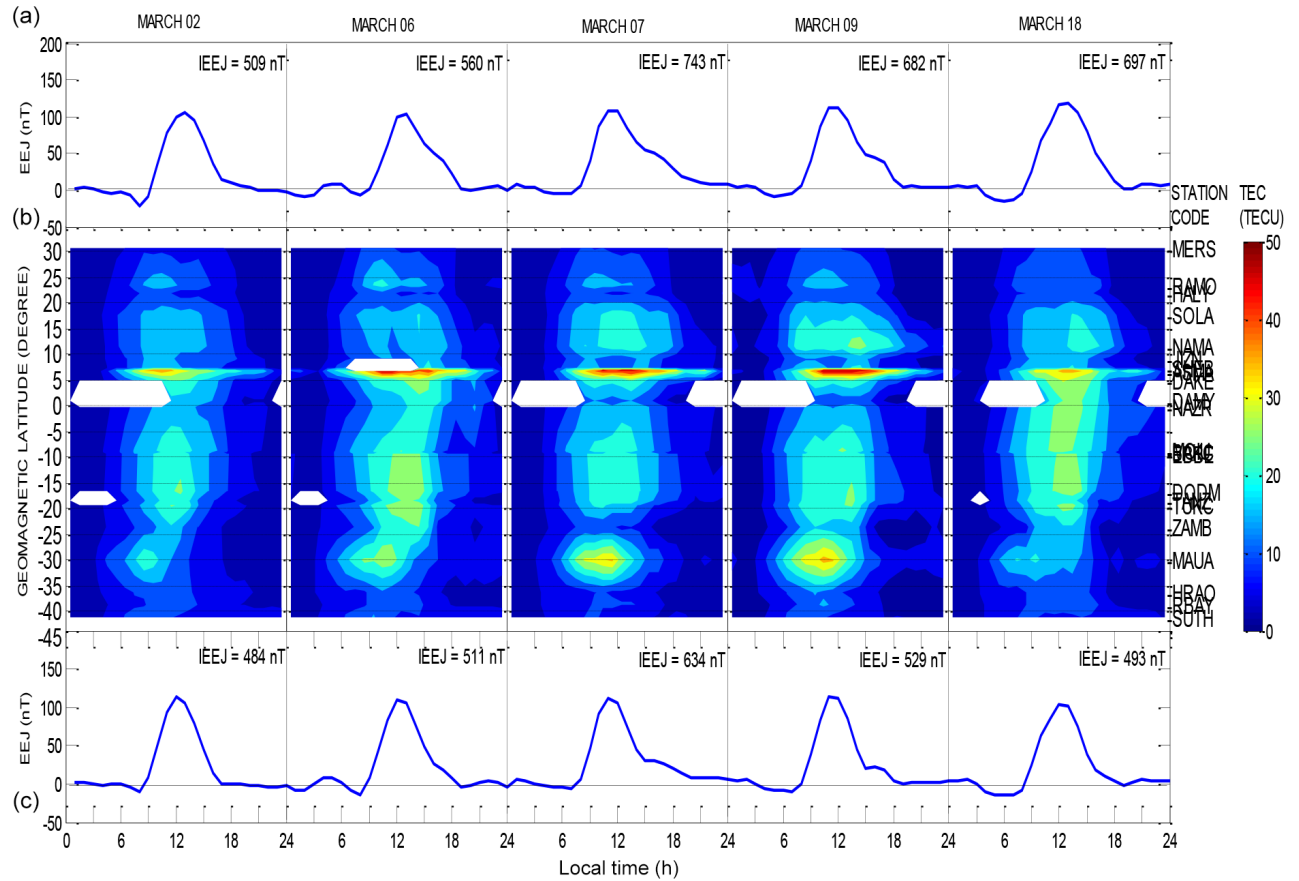

Figure 4. The TEC magnitudes of the quietest days, equatorial electrojet (EEJ) strength, and integrated EEJ strength in March.

highest IEEJ strength observed in the Northern Hemisphere was $\sim 743 \mathrm{nT}$ and the maximum southern hemispheric IEEJ recorded was $\sim 634 \mathrm{nT}$.

The variations in TEC (Fig. 5b) in April that produced the EIA crests were in the range of $\sim 16$ and $\sim 47$ TECU.
The EIA crests were well-developed in both hemispheres on 2 April with maximum value of $\sim 47$ TECU in the Northern Hemisphere at ASMA. The southern EIA crest with a magnitude of $\sim 23$ TECU straddled TANZ and TUKC. A moderately developed EIA crest was observed on 4 April in the 


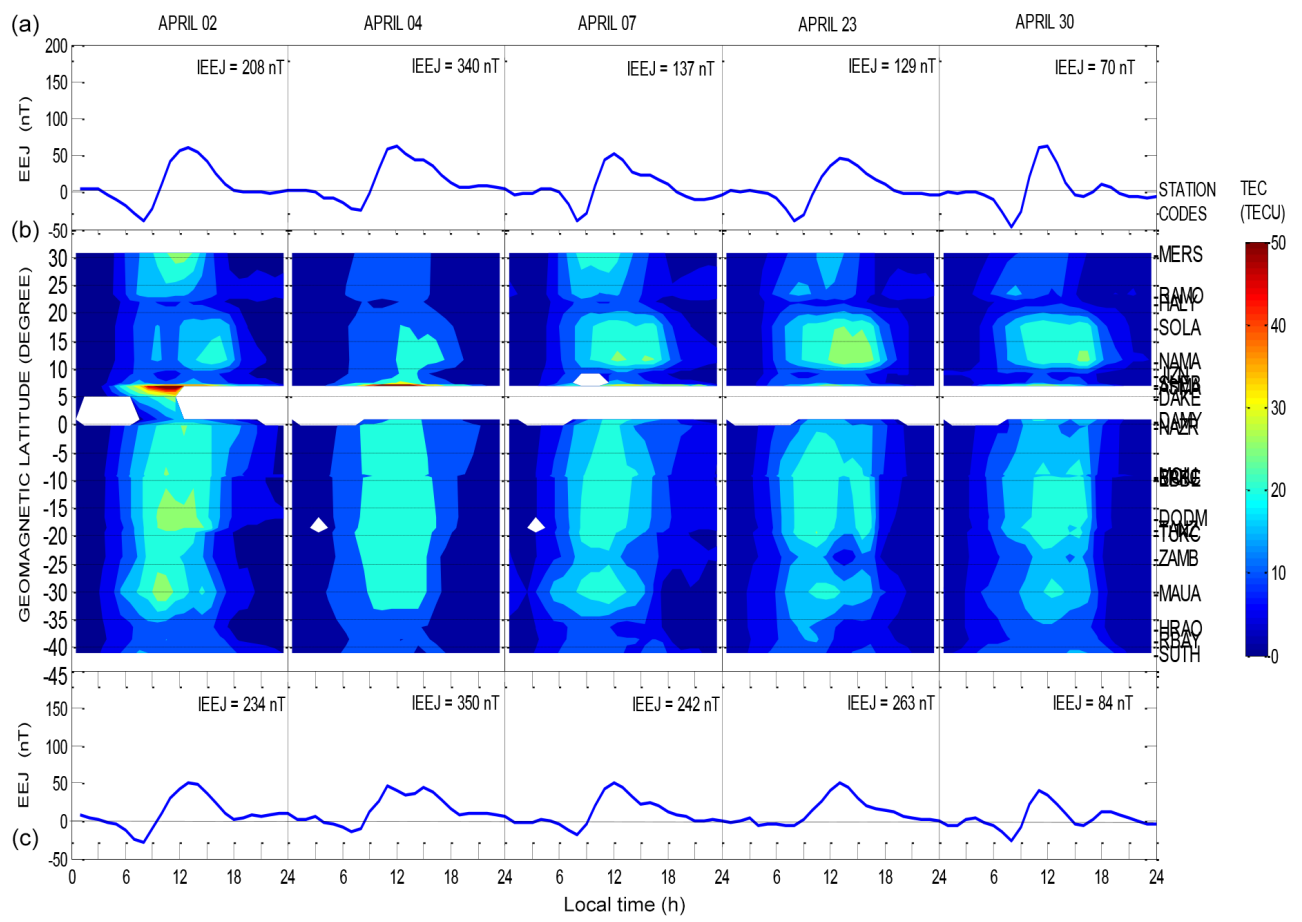

Figure 5. The TEC magnitudes of the quietest days, equatorial electrojet (EEJ) strength, and integrated EEJ strength in April.

Northern Hemisphere (ASMA), compared to a weakly developed EIA crest in the Southern Hemisphere that straddled DAMY and TUKC. The EIA crest straddling NAMA and SOLA on 23 April was higher $(\sim 25 \mathrm{TECU})$ than the EIA crest at ASMA ( 23 TECU) in the Northern Hemisphere. In the Northern Hemisphere on 30 April, a maximum EEJ strength of $\sim 60 \mathrm{nT}$ was observed around 12:00 LT, associated with a CEJ value of $\sim-50 \mathrm{nT}$ around 08:00 LT. The highest IEEJ strength estimate was $\sim 340 \mathrm{nT}$ in the Northern Hemisphere and $\sim 350 \mathrm{nT}$ in the Southern Hemisphere on 4 April.

On some of the investigated quiet days, we observed increments in TEC magnitude similar to EIA crests in the low latitudes at MAUA $\left(\sim 30^{\circ} \mathrm{S}\right)$, which is a middle-latitude station. The highest was observed on 7 March, with a value of $\sim 33$ TECU.

\section{Discussion}

Investigation into the TEC from 22 GPS stations and three MAGDAS over the equatorial and low-latitude ionosphere in Africa has been carried out. The records of horizontal $\mathrm{H}$-field component from MAGDAS were used to estimate the $S_{\mathrm{q}}$ current and EEJ and IEEJ strengths. The results obtained from TEC and EEJ strength generally showed trend of increases in the morning and declines at dusk. Other features such as daytime depression in TEC magnitudes over the EIA crest and daytime CEJ from the EEJ strength are also revealed.
In this present work, IEEJ strength up to a daily maximum (herein IEEJ) suggested by Venkatesh et al. (2015) was employed. Our findings on the EIA morphology in AfricaMiddle East revealed that the rate of plasma production, loss, and transport mechanisms are different over the two hemispheres. This is in agreement with the suggestions of Chen et al. (2008) in regard to differences in dynamo electric fields at equatorial low latitudes of the two hemispheres. In this work, we will further discuss these differences in both hemispheres, including the E-F coupling, using TEC latitudinal signatures straddling the hemispheres as one of the transportation processes in the ion continuity equation. This will also show meridional wind effect (de Paula et al., 2015).

Concerning the differences in the low-latitude equivalent dynamo electric field, we observed higher EIA crests in the Northern Hemisphere compared to the corresponding EIA crests in the Southern Hemisphere on all of the quiet days we investigated. This is one of the consequences of initiating asymmetry of EIA crest, apart from meridional neutral wind, which will be discussed later. In addition to our findings that the magnitude of EIA crest in the Northern Hemisphere is higher than in the Southern Hemisphere, we also found that the location of the EIA crests in the Northern Hemisphere straddled $\sim 7$ and $\sim 11^{\circ} \mathrm{N}$. In the works of Chen et al. (2008), EIA crests straddled $\sim 20$ and $\sim 23^{\circ} \mathrm{N}$. In the Southern Hemisphere, we found visible EIA crests $\sim 17$ and $\sim 19^{\circ} \mathrm{S}$ and the EIA crests from Chen et al. (2008) were reported to be $\sim 5$ and $\sim 8^{\circ} \mathrm{S}$. This is clearer evidence of 
the differences in the EIA morphology between the AfricanMiddle Eastern and Asian sectors.

Moreover, it is worthy to note that the EEJ strength, IEEJ strength up to a daily maximum and IEEJ strength for a whole day, all together, are driven by the equatorial eastward electric field. This is one of the parameters of transportation in the ion continuity equation (Rishbeth, 1962; Lei et al., 2008). Significantly, it drifts plasma from the equatorial latitude along the magnetic field lines to higher latitudes under the influence of gravity and pressure gradients (Martyn, 1947; Bolaji et al., 2013). A good representation of the equatorial eastward electric field is EEJ strength (Anderson et al., 2002), and IEEJ strength up to a daily maximum (Venkatesh et al., 2015). These ionospheric parameters have the capacity to majorly control the extent of plasma transportation at low latitudes of the ionosphere, while the transportation control due to meridional neutral wind is minimal.

Our results in January showed experimental evidence of how EEJ-IEEJ strength majorly controls plasma transportation over the low latitude. For example, the latitudinal extent of the EIA crest on 7 January in the Northern Hemisphere was obviously controlled by the highest EEJ-IEEJ strength. Similar controls of the farthest EIA crest due to the highest EEJ-IEEJ strength in the Northern Hemisphere were also seen on 7 March. These indicate that the available meridional neutral winds that could have modulated the EEJIEEJ strength on these days were superimposed by stronger eastward electric fields around the equatorial latitude. Our observations are in agreement with the works of Sethia et al. (1980), Balan and Iyer (1983), Rama Rao et al. (1984), Raghavarao et al. (1988), Rastogi and Klobuchar (1990), Chen et al. (2008), and Venkastesh et al. (2015), who investigated EIA morphology in different regions and reported that EEJ-IEEJ strength is very effective in the movement of EIA crests to higher latitudes.

On some of the quiet days that were not significantly controlled by EEJ-IEEJ strength, the thermospheric meridional neutral winds could either strengthened or inhibit the EEJIEEJ strength in regard to moving plasma to higher latitudes and initiating latitudinal asymmetry in the location of EIA crests (Bramley and Peart, 1965; Bramley and Young, 1968; Batista et al., 2011). Although we do not have wind measurements over Africa-Middle East in 2009, the latitudinal variability of TEC we are presently investigating could be used to infer the meridional wind effects during the day. For example, 10 February and 4 April, where the highest EEJ-IEEJ strengths failed to produce the corresponding farthest EIA crest in the Northern Hemisphere, were due to irregular variability of TEC at higher latitudes, which was characterized by steep daytime depression veering alternately to right and left. Similar slight depression in the latitudinal profile of TEC was employed by de Paula et al. (2015) to quantify equatorward meridional neutral wind effects on the weakening of scintillation over the South American sector during sudden stratospheric warming events. Therefore, a well-shaped and broader EIA crest at the farthest latitude without depression signifies that meridional wind effect is not significant. Otherwise, slight or higher depression at the latitudinal extent of plasma is evidence that meridional wind effect is in place.

An interesting feature observed from our investigations during the day (found on at least 1 of the days investigated in each month) is two EIA crests at different latitudes within the low latitudes of the Northern Hemisphere (latitudinal twin EIA crests). One of the latitudinal twin crests is always found at $\sim 7^{\circ} \mathrm{N}$ (ASMA). The other one is found between latitudes $\sim 11$ and $\sim 18^{\circ} \mathrm{N}$, straddling NAMA and SOLA and sometimes alternating between them. Both EIA crests (ASMA and the one straddling NAMA and SOLA) were separated by consistent reduced TEC at $\sim 8^{\circ} \mathrm{N}$ (SHEB) and sometimes extended to include latitude $\sim 9^{\circ} \mathrm{N}$ (JIZN). We observed that the EIA crest was not always higher at ASMA compared to NAMA because on some days (11 and 12 January) EIA crests at NAMA were higher than those found at ASMA.

These rare scenarios could result from inconsistent transportation of plasma to higher latitudes. We suspect that the period of initial steep pressure gradient associated with gravitational force, which assisted vertical drift in transporting the plasma along the magnetic field lines up to $\sim 11^{\circ} \mathrm{N}$ is shorter. The consequence is a shallow pressure gradient and gravitational force that relax for a longer period at $\sim 7^{\circ} \mathrm{N}$ and leave reduced TEC around $\sim 8$ and $\sim 9^{\circ} \mathrm{N}$. This feature needs further investigation to identify the underlying parameter that is triggering it.

As can be observed, these latitudinal twin EIA crests are not the same as the twin EIA crests prior to noon and during the afternoon period reported by Venkatesh et al. (2015). They reported that double-peak observations from EEJ strength that simultaneously produce twin EIA crests are rare. Our results on 7 April in the Northern Hemisphere without two peaks in the daytime variability of EEJ strength had corresponding twin EIA crests, one around noon-afternoon and the other in the afternoon period. The present study further adds that all the twin EIA crests may not be associated with a twin peak EEJ strength. From our results that showed a maximum magnitude of $\sim 49 \mathrm{nT}$ around 12:00 LT associated with a significant CEJ $(\sim 48 \mathrm{nT})$ around 09:00 LT, this EEJ strength variability (7 April) indicates a weaker eastward daytime electric field during sunrise hours and that a pre-noon EIA crest could not be formed. Investigations into pre-noon peaks of TEC and electron density at the F2-layer $(\mathrm{NmF} 2)$ over the equatorial latitudes have been made by Skinner (1966), Rajaram (1977), Radicella and Adeniyi (1999), Lee and Reinisch (2006), and Bolaji et al. (2012, 2013). They reported that development of a prenoon EIA crest is due to a stronger eastward daytime electric field compared to photoionization near noon. Hence, higher noon-afternoon EIA crest is due to stronger photoionization that supports a weak eastward electric field at noon. The reduced post-noon EIA crest is evidence of longer photoion- 
ization refilling the abrupt plasma loss due to an extremely weak eastward electric field in the afternoon.

Furthermore, the higher EIA crests we observed in March compared to other months are in agreement with the works of Venkatesh et al. (2015). Barbara et al. (1980), Rama Rao et al. (1985), and Bolaji et al. (2012) also reported higher monthly variability of TEC in March and higher seasonal variability of TEC in equinoctial months (March, April, September, and October) at low latitudes. We therefore suggest that these may be responsible for most of the higher EIA crest values found at ASMA in March on most days and on 2 April compared to other months.

\section{Conclusions}

We have observed and investigated EIA over Africa-Middle East during a year of deep minimum. Our results are similar to the works of Dunford (1967), Rama Rao et al. (1984), Raghavarao et al. (1988), Chen et al. (2008), and Venkatesh et al. (2015) in other sectors in regard to EEJ and IEEJ strength controlling EIA morphology. We report a few cases that are not fully controlled by EEJ-IEEJ using TEC latitudinal distributions to characterize thermospheric meridional neutral wind effect. We found that EIA crests in the Africa-Middle East have a higher magnitude in the Northern Hemisphere compared to the Southern Hemisphere, which contrasts the study of Chen et al. (2008) in the Asian sector. We found two EIA crests at different latitudes in the low latitudes of the Northern Hemisphere, which has never been reported before and needs further investigation regarding which mechanisms among the transport parameters are responsible for triggering such a feature.

\section{Data availability}

African Geodetic Reference Frame data can be accessed online at http://www.afrefdata.org/. International GNSS service is also available online at http://www.igs.org/. The Magnetic Data Acquisition System (MAGDAS) used for this work is available at the International Centre for Space Weather Science and Education (ICSWSE, 2011) website (http://magdas. serc.kyushu-u.ac.jp/request/index.html) upon request from the project leader of MAGDAS/CPMN, A. Yoshikawa (email address: yoshi@geo.kyushu-u-ac.jp).

Competing interests. The authors declare that they have no conflict of interest.

Acknowledgement. One of the authors, Bolaji Olawale Segun, acknowledges the African Geodetic Reference Frame, International GNSS service, and Magnetic Data Acquisition System (MAGDAS) groups for making the data available for this study. Bo- laji Olawale Segun also acknowledges the two anonymous reviewers for the painstaking reviews that significantly improved this work.

The topical editor, J. Makela, thanks the two anonymous referees for help in evaluating this paper.

\section{References}

African Geodetic Reference Frame: available at: http://www. afrefdata.org, last access: 18 February 2015.

Anderson, D., Anghel, A., Yumoto, K., Ishitsuka, M., and Kudeki, E.: Estimating day time vertical ExB drift velocities in the equatorial F-region using ground-based magnetometer observations, Geophys. Res. Lett., 29, 37-1-37-4, doi:10.1029/2001GL014562, 2002.

Appleton, E. V.: Two anomalies in the ionosphere, Nature, 157, 691-693, 1946.

Balan, N. and Iyer, K. N.: Equatorial anomaly in ionospheric electron content and its relation to dynamo currents, J. Geophys. Res., 88, 10259-10262, 1983.

Barbara, A. K., Devi, M., Bardoli, P., and Rehman, K.: Ionosheric effect observed at Gauhati during the solar eclipse of February 16, 1980, Proc Int. Symp. Beacon Satellite studies on the Earth's Environment, 387 pp., 1980.

Batista, I. S., Diogo, E. M., Souza, J. R., Abdu, M. A., and Bailey, G. J.: Equatorial ionization anomaly: The role of thermospheric wind and the effect of the geomagnetic field secular variation, Aeronomy of the Earth's Atmosphere and Ionosphere, Springer Dordrecht Heidelberg, London New York, 2011.

Bolaji, O. S., Adeniyi, J. O., Radicella, S. M., and Doherty P. H.: Variability of total electron content over an equatorial West African station during low solar activity, Radio Sci. 47, RS1001, doi:10.1029/2011RS004812, 2012.

Bolaji, O. S., Adeniyi, J. O., Radicella, S. M., and Doherty, P. H.: Total electron content over and magnetic field intensity over Ilorin, Nigeria, J. Atmos. Sol.-Terr. Phy., 98, 1-11, 2013.

Bolaji, O. S., Rabiu, A. B., Bello, O. R., Yoshikawa, A., Yumoto, K., Odeyemi, O. O., and Ogunmodimu O.: Spatial variability of solar quiet fields along $96^{\circ}$ magnetic meridian in Africa: Results from MAGDAS, J. Geophys. Res., 120, 3883-3898, doi:10.1002/2014JA020728, 2015.

Bramley, E. N. and Peart, M.: Diffusion and electromagnetic drift in the equatorial F2-region, J. Atmos. Terr. Phys., 27, 1201, doi:10.1016/0021-9169(65)90081-4, 1965.

Bramley, E. N. and Young, M.: Winds and electromagnetic drifts in the equatorial F2-region, J. Atmos. Terr. Phys., 30, 99-111, doi:10.1016/0021-9169(68)90044-5, 1968.

Chen, C. H., Liu, J. Y., Yumoto, K., Lin, C. H., and Fang, T. W.: Equatorial ionization anomaly of the total electron content and equatorial electrojet of ground-based geomagnetic field strength, J. Atmos. Terr. Phys., 70, 2172-2183, 2008.

de Abreu, A. J., Fagundes, P. R., Gende, M., Bolaji, O. S., de Jesus, R., and Brunini, C.: Investigation of ionospheric response to two moderate geomagnetic storms using GPS-TEC measurements in the South American and African sectors during the ascending phase of solar cycle 24, Adv. Space Res., 53, 1313-1328, doi:10.1016/j.asr.2014.02.011, 2014. 
de Paula, E. R., Jonah, O. F., Moraes, A. O., Kherani, E. A., Fejer, B. G., Abdu, M. A., Muella, M. T. A. H., Batista, I. S., Dutra, S. L. G., and Paes, R. R.: Low-latitude scintillation weakening during sudden stratospheric warming events, J. Geophys. Res.Space, 120, 2212-2221, doi:10.1002/2014JA020731, 2015.

Dunford, E.: The relationship between the ionospheric equatorial anomaly and the E-region current system, J. Atmos. Terr. Phys., 29, 1489-1498, 1967.

ICSWSE (International Centre for Space Weather Science and Education): Kyushu University, Japan, available at: http://magdas. serc.kyushu-u.ac.jp/, last access: 16 March 2011.

International GNSS service: available at: http://www.igs.org, last access: 17 October 2016.

Joseph, O. O., Yamazaki, Y., Cilliers, P., and Mito, O. C.: A study on the response of the equatorial ionization anomaly over the East Africa sector during the geomagnetic storm of November 13, 2012, Adv. Space Res., 55, 2889-2898, doi:10.1016/j.asr.2015.03.001, 2015.

Lee, C. C. and Reinisch, B. W.: Quiet-condition $h m \mathrm{~F} 2, N m \mathrm{~F} 2$, and $B_{0}$ variations at Jicamarca and comparison with IRI-2001 during solar maximum, J. Atmos. Terr. Phys., 68, 2138-2146, doi:10.1016/j.jastp.2006.07.007, 2006.

Lei, J., Wang, W., Burns, A. G., Solomon, S. C., Richmond, A. D., Wiltberger, M., Goncharenko, L. P., Coster, A., and Reinisch, B. W.: Observations and simulations of the ionospheric and thermospheric response to the December 2006 geomagnetic storm: Initial phase, J. Geophys. Res., 113, A01314, doi:10.1029/2007JA012807, 2008.

Martyn, D. F.: Atmospheric tides in the ionosphere - I. Solar tides in the F2 region, P. R. Soc. Lond. A, 189, 241-260, 1947.

Moffett, R. J. and Hanson, W. B.: Effect of ionization transport on the equatorial F-region, Nature, 206, 705-706, doi:10.1038/206705a0, 1965.

Pedatella, N. M., Liu, H. L., Sassi, F., Lei, J., Chau, J. L., and Zhang, X.: Ionosphere variability during the 2009 SSW: Influence of the lunar semidiurnal tide and mechanisms producing electron density variability, J. Geophys. Res.-Space, 119, 38283843, doi:10.1002/2014JA019849, 2014.

Radicella, S. M. and Adeniyi, J. O.: Equatorial ionospheric electron density below the F2 peak, J. Geophys. Res., 34, 1153-1163, 1999.

Raghavarao, R., Nageswararao, J., Hanumath, S., Vyas, G. D., and Sriramarao, M.: Role of equatorial ionization anomaly in the initiation of equatorial spread F, J. Geophys. Res.-Space, 93, 5959_ 5964, 1988.
Rajaram G.: Structure of the equatorial F-region, topside and bottomside-a review, J. Atmos. Terr. Phys., 39, 1125-1144, doi:10.1016/0021-9169(77)90021-6, 1977.

Rama Rao, P. V. S., Das Gupta, A., Klobuchar, J. A., and Rastogi, R. G.: Electrojet Control over the Equatorial anomally in TEC and equivalent slab thickness, Proc. Int. Symp. Beaco Satellite studies on Earth's Environment (India), National Physical Laboratory of India, New Delhi, 393-400, 1984.

Rama Rao, P. V. S., Niranjan, K., Ramana Rao, B. V., Rao, B. V. P. S., and Prosad, D. S. V. V. D.: Study of the Solar Cycle Variation of some Ionospheric Phenomena Observed in TEC and Scintillation measurements made from low latitude station, Waltair $\left(17.7^{\circ} \mathrm{N}\right)$, India, Proc URS/PS Conference, Sydney, Australlia, 1985.

Rastogi, R. G. and Klobuchar, J. A.: Ionospheric electron content within the equatorial F2 layer anomaly belt, J. Geophys. Res., 95, 45-52, 1990.

Rishbeth, H.: Atmospheric composition and F layer of the ionosphere, Planet. Space Sci., 9, 149-152, doi:10.1016/00320633(62)90002-8, 1962.

Rush, C. M., Rush, S. V., Lyons, L. R., and Venkateswaran, S. V.: Equatorial anomaly during a period of declining solar activity, Radio Sci., 4, 824-841, doi:10.1029/RS004i009p00829, 1969.

Sethia, G., Rastogi, R. G., Deshpande, M. R., and Chandra, H.: Equatorial electrojet control of the low latitude ionosphere, J. Geomagn. Geoelectr., 32, 207-216, doi:10.5636/jgg.32.207, 1980.

Skinner, N. J.: Measurements of total electron content near the magnetic equator, Planet Space Sci. 14, 1123-1129, doi:10.1016/0032-0633(66)90026-2, 1966.

Uemoto, J., Maruyama, T., Saito, S., Ishii, M., and Yoshimura, R.: Relationships between pre-sunset electrojet strength, prereversal enhancement and equatorial spread-F onset, Ann. Geophys., 28, 449-454, doi:10.5194/angeo-28-449-2010, 2010.

Venkatesh, K., Fagundes, P. R., Prasad, D. S. V. V. D., Denardini, C. M, de Abreu, Jesus R., and Gende, M.: Day-to-day variability of equatorial electrojet and its role on the day-to-day characteristics of the equatorial ionization anomaly over the Indian and Brazilian sectors, J. Geophys. Res.-Space, 120, 9117-9131, doi:10.1002/2015JA021307, 2015. 